\title{
Systematic review of the effects of environmental factors on virus inactivation: implications for coronavirus disease 2019
}

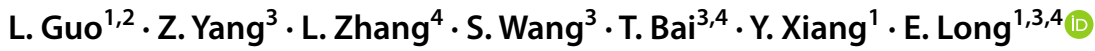

Received: 16 September 2020 / Revised: 16 March 2021 / Accepted: 17 June 2021 / Published online: 17 July 2021

(c) Islamic Azad University (IAU) 2021

\begin{abstract}
Environmental factors such as temperature and relative humidity can affect the inactivation and transmission of coronaviruses. By reviewing medical experiments on virus survival and virus transmission between infected and susceptible species in different temperature and humidity conditions, this study explores the influence of temperature and relative humidity on the survival and transmission of viruses, and provides suggestions, with experimental evidence, for the environmental control measures of Coronavirus Disease 2019. The results indicated that (1) virus viability and infectivity is increased at a low temperature of $5{ }^{\circ} \mathrm{C}$ and reduced at higher temperatures. (2) Virus survival and transmission is highly efficient in a dry environment with low relative humidity, and also in a wet environment with high relative humidity, and it is minimal at intermediate relative humidity. Therefore, in indoor environments, the lack of heating in winter or overventilation, leading to low indoor temperature, can help virus survival and help susceptible people being infected. On the contrary, modulating the indoor relative humidity at an intermediate level is conducive to curb epidemic outbreaks.
\end{abstract}

Keywords Coronavirus Disease 2019 Environmental control strategies $\cdot$ Temperature $\cdot$ Relative humidity $\cdot$ Virus infectivity $\cdot$ Virus survival

\section{Introduction}

The World Health Organization (WHO) declared a global pandemic for the outbreak of coronavirus disease (COVID19), which is a highly transmittable and pathogenic viral infection caused by severe acute respiratory syndrome coronavirus 2 (SARS-CoV-2) (Sanders et al. 2020; WHO 2020). SARS-CoV-2 is majorly transmitted from human-to-human

Editorial responsibility: Samareh Mirkia.

$\triangle$ E. Long

longes2@163.com

1 MOE Key Laboratory of Deep Earth Science and Engineering, Institution of Disaster Management \& Reconstruction, Sichuan University, Chengdu, China

2 College of Culture and Art, Chengdu University of Information Technology, Chengdu, China

3 College of Architecture and Environment, Sichuan University, Chengdu, China

4 Department of Solid Waste Treatment Technology, Sichuan Environmental Protection Key Laboratory of Pollution Control for Heavy Metals, Sichuan Academy of Environmental Sciences, Chengdu, China via direct or indirect contact between people and with contaminated surfaces (Prather et al. 2020; Huang et al. 2020). The transmission of SARS-CoV-2 appears to be primarily via aerosols (Stadnytskyi et al. 2020; Morawska and Milton 2020) and recent studies have shown that SARS-CoV-2 is able to remain infectious in airborne particles for greater than $3 \mathrm{~h}$ (van Doremalen et al. 2020; Smither et al. 2020). Although many countries have not acknowledged it, recent evidence strongly suggests that airborne transmission of SARS-CoV-2 is likely (Tellier et al. 2019; Asadi et al. 2020; Hadei et al. 2020; Hsiao et al. 2020; Liu et al. 2020; Morawska and Cao 2020; National Academies of Sciences, Engineering, and Medicine 2020; Prather et al. 2020; van Doremalen et al. 2020). The virus has gained global attention due to its highly contagious nature and the uncertainty of standard vaccines (Lu 2020). A number of vaccines are under development using different platforms and clinical trials are ongoing in different countries, but even if they are licensed it will need time until reach a definite conclusion about their real safety and efficacy (Al-Hatamleh et al. 2021; Dos Santos 2021; Glied 2021; Chitrakar et al. 2021). Therefore, besides wearing a mask and maintaining social distancing, environmental implications that can influence 
the vitality and infectivity of SARS-CoV-2 in transmission routes should be considered as an alternative choice (Yao et al. 2020).

The coronavirus transmission can be affected by various factors such as climate conditions (majorly temperature, humidity and wind speed), population density, and available medical facilities (Dalziel et al. 2018). In fact, a number of studies have proved that temperature and relative humidity $(\mathrm{RH})$ can affect virus survival and infectivity (Chan et al. 2020; Morawska and Cao 2020; Zhang et al. 2020; Guo et al. 2021; Kwon et al. 2021). Noti et al. (2013) showed that when the ambient temperature was $20^{\circ} \mathrm{C}$, the number of infectious $\mathrm{H} 1 \mathrm{~N} 1$ influenza viruses was significantly lower than $20 \%$ at RH45\%. Marr et al. (2019) found that temperature and RH would affect the stability of the viruses, in which RH determined the evaporation rate of the virus-containing droplets. Evaporation would then affect the size, physical fate and chemical microenvironment of the droplet, which in turn would affect the chemical microenvironment of the viruses, and determine the survival of the viruses. Kumar et al. (2020) found that susceptibility and inactivation led to seasonal epidemics of SARS-COV-2, meaning that temperature had an important influence on virus inactivation. Sattar et al. (1984) discussed the half-life of aerosolized viruses in a rotating drum and found that the relative viability rate varies due to different temperature and $\mathrm{RH}$ conditions. It was also verified by other experiments (Moe and Harper 1983; Ijaz et al. 1985a, b; Gaunt et al. 2010; Kampf et al. 2020). Additionally, Chan et al. (2011) showed that low temperature and low RH increased the survival time of viruses on contaminated surfaces, and other experiments found that virus survival could be reduced the lowest rate of $3-4.7 \%$ at a certain temperature and RH (Ijaz et al. 1985a, b; Pyankov et al. 2018). These results indicate that temperature and $\mathrm{RH}$ have a significant impact on the inactivation of viruses when they leave the host.

On the other hand, temperature and $\mathrm{RH}$ also have an influence on virus infectivity and transmission when patients and susceptible individuals are confined to a specific space (Bukhari 2020; Alvarez-Ramirez and Monica 2020). A research team from the University of Maryland believed that the spread of COVID-19 had obvious seasonality, and the increasing temperature was likely to be an important reason for the significant decline of confirmed cases in Wuhan after March (Sajadi et al. 2020). Wang et al. (2021) pointed out that the number of confirmed cases and propagation coefficients would be affected quantitatively by every $1{ }^{\circ} \mathrm{C}$ increase. When considering ambient air humidity, an important role of humidity was found in rapid transmission of COVID-19 within the New York city (Bashir et al. 2020). Pani et al. (2020) found the positive correlation of humidity with COVID-19 spread based on the daily data provided by Ministry of
Health, Singapore. Similarly, a positive correlation was found between COVID-19 and RH $(r=0.106, P=0.001)$ in Kuala Lumpur, Malaysia (Suhaimi et al. 2020). Therefore, temperature and RH conditions can affect the viability and infectivity of viruses in the transmission routes. As the macroscopic climate conditions have many influencing factors, laboratory experiments can define the effects of temperature and RH more effectively.

During the community outbreaks of COVID-19, regulation of indoor environments has attracted much attention. The adjustment of temperature and RH mainly depends on the air conditioning system or other humidifiers. However, there is a great debate on whether air conditioners can transmit viruses (Kwon et al. 2020). It has been proven that virus transmission on the cruise ship 'Princess Diamond' has no relationship with the operation of the airconditioning system (Kwon et al. 2020; Sekizuka et al. 2020), but the virus transmission has often occurred in well air-conditioned environments such as hospitals or hotels in some countries which has intensive use of airconditioning (Chan et al. 2020). While the WHO and most national health agencies have no evidence to prove that air-conditioning system can contribute to virus transmission, government agencies and local authorities in some countries develop the operation plan and strategies for airconditioning system based on the notion that air-conditioning can transmit viruses (Zhao et al. 2020). However, the guidelines or precaution strategies based on inference or hypothesis are unconvincing (Zhao et al. 2020). Especially, emphasis on building ventilation without considering the coupling of indoor temperature and $\mathrm{RH}$ is negative to the thermal comfort of indoor environments and the spread of COVID-19 epidemic. As a result, it is significant to improve the prevention and control strategy of COVID19 by clarifying the influence of temperature and $\mathrm{RH}$ on virus transmission with experimental support.

To sum up, although the existing literature reports qualitative and quantitative studies on the effects of temperature and $\mathrm{RH}$ on virus survival and infectivity, there is still a lack of systematic study. Because different scholars may have different experimental methods, detection methods and experimental environments, the scattered results may lead to uncertainty in the horizontal comparison of experimental results, and the information conveyed may be biased. In addition, government departments may introduce unconvincing policies without figuring out the effects of environmental factors on virus inactivation, which is negative to epidemic prevention and control. Therefore, this study reviews a number of experiments on virus inactivation in different temperature and RH conditions, integrates and analyzes the relevant experimental data, and comprehensively analyzes the influence law of temperature and $\mathrm{RH}$ on virus survival 
and infectivity. It also can put forward suggestions for controlling the outbreak of COVID-19 from the perspective of environment.

\section{Materials and methods}

The influence of temperature and RH on virus transmission among susceptible individuals depends on two major aspects. Firstly, when a virus enters a certain environment after leaving the host in droplets or sputum, there is an influence due to temperature and RH on virus survival. Secondly, when a virus enters a susceptible animal or individual in some way, temperature and RH have effects on the infection rate. Because the virus is of small size and can cause great harm, the related experiments should be conducted in a strict operational condition. In addition, because of the ethical restriction, it is impossible to do the human infection experiment, and these experiments are usually accomplished using animal models. Taking this as a clue, terms of "environment", "temperature", "humidity", "coronavirus/ influenza virus", "virus survival", and "virus transmission" were used to search in the Web of Science to identify the related studies. The studies were screened by reading abstracts, and references in some important studies were read extensively. In addition, in order to identify the effects of ambient temperature and RH on virus viability under different conditions or virus infectivity in a restricted space, these studies were divided into three groups: virus survival on surfaces, virus survival in the air and virus transmission in animal models, according to their different research and experimental methods. Finally, 22 representative studies were selected, including nine representative experiments on virus survival on surfaces, nine experiments on virus survival in the air, and four experiments on animal models.

Due to the complexity of the problem, the existing medical experiments on virus survival are relatively scattered. By viewing the existing literature, the research results of virus survival on the surface of objects were usually given in terms of the time required for virus decay to a certain concentration or the curve of virus concentration changing with time. Therefore, in this study, experimental data in the relevant literature were calculated by different methods. For the experiments of virus survival on surfaces or in the air, firstly, if the specific data of experimental temperature, humidity and virus survival rate were provided in the literature, they were directly counted into Excel. Secondly, if the curve of virus relative survival rate with temperature and humidity, the GetData Graph Digitizer software was used to obtain the virus relative survival rate measured at each temperature and humidity node in the experiment, and then the data were counted into Excel for analysis. Furthermore, experiments that provided virus decay rate constants but cannot calculate the survival rate of viruses were not analyzed. For experiments of animal models, the data of temperature, $\mathrm{RH}$ and animal survival rate or infection rate were extracted and analyzed. In this study, 118 set of data were analyzed, and then the effects of ambient temperature and RH on the survival of viruses on surfaces, the survival of aerosolized viruses in the air, and viral infectivity in animal models were studied. It should be noted that, considering the safety of the experimental process with highly infectious human respiratory viruses, many researchers choose closely related viral surrogates, including the murine hepatitis virus (MHV), transmissible gastrointestinal virus (TGEV) and other animal viruses, as well as phage phi 6 and MS2, etc. Therefore, these virus surrogates are also included in this study.

\section{Results and discussion}

\section{Effects of temperature and $\mathrm{RH}$ on virus survival}

A virus can survive in the environment in two forms after it leaves the host via a respiratory fluid. One is falling on various surfaces. If a virus contacts a susceptible individual, it will cause the risk of infection. The second form is floating in the air. If a virus is inhaled by susceptible individuals, it will cause transmission and infection. As virus survival depends on a respiratory fluid, and sputum droplets and aerosols must undergo the process of thermal mass transfer, evaporation and concentration in a specific environment, it leads to decreased water and nutrients, increased salt concentration and acid-base balance destruction. The living environment of the virus deteriorates rapidly. Therefore, temperature and RH have an important influence on virus survival.

\section{Survival of viruses on surfaces}

In order to explore the changes of virus viability after sputum droplets and aerosols were deposited on the surface, the experimental methods were usually as follows. Firstly, a certain volume of various viruses was titrated on different surfaces. Then surface specimens were placed in an adjustable environment and taken out at different time nodes. Next, changes of virus decay and the relative survival rate were quantitatively analyzed by plaque assay or real-time qPCR analysis to explore the varying influence of temperature and RH on the virus inactivation with increased time. Different studies have differences in the species of test viruses, the surface materials affecting titration (culture media conducive to survival or stainless steel surfaces), and the volume of titrated droplets. However, all of these studies discussed the survival of a specific virus on the surface by changing the temperature and $\mathrm{RH}$ parameters, so the results have scientific 
value. Table 1 summarizes a number of important research conditions and results of the representative studies.

In order to identify the influence of temperature, experimental data with similar RH conditions were analyzed. Figure 1 indicated that when $\mathrm{RH}$ was at certain levels, the relative survival rate of the viruses generally has a significant decreasing trend with increase of temperature, and most viruses lost their viability at high temperature $\left(>35{ }^{\circ} \mathrm{C}\right)$, because high temperature accelerates the evaporation of surface droplets, and the subsequent salt concentration and acid-base balance destruction lead to increased virus decay. (2) The relative survival rate of the Phi6 virus was significantly higher than that of TGEV and MHV at $15^{\circ} \mathrm{C}$, mainly because it had an exposure period of $2 \mathrm{~h}$, while the others were assessed after being exposed for $24 \mathrm{~h}$. It shows that a long exposure time can lead to a decrease of viral viability.

Figure 2 representatively presents the experimental results from four studies, in which temperature was controlled at a comfortable laboratory environment $\left(19-25^{\circ} \mathrm{C}\right)$. It was found that (1) for all species of viruses, the relationship between virus viability and RH showed a distinct U-shaped pattern. Most viruses survived well at low and extremely high $\mathrm{RH}$, and inactivated quickly at intermediate $\mathrm{RH}(50-70 \%)$. It indicates that modulating the $\mathrm{RH}$ at a moderate level $(50-70 \%)$ is positive in reducing virus survival and inhibiting virus spread. (2) It was notable that for TGEV at $20{ }^{\circ} \mathrm{C}$ and $\mathrm{MS} 2$ virus at $22{ }^{\circ} \mathrm{C}$, the U-shaped curves were slightly different from the others. Their curves had a sharp bottom at RH50-55\%, may be due to insufficient RH operating points.

\section{Survival of aerosolized viruses in the air}

The general experimental methods to explore the timedependent changes of the viability of aerosolized viruses floating in the air were as follows. Firstly, a certain volume of virus fluid was aerosolized with a nebulizer into $1-5 \mu \mathrm{m}$ toxic particles, and they were suspended in closed chambers or rotating drums. Air samples were collected at different time points. The changes of virus decay and relative survival rate were quantitatively titrated by plaque assay or real-time qPCR analysis, in order to analyze the effects of temperature and $\mathrm{RH}$ on the changes of virus vitality and virus decay with increased time. Although there are differences in the species of test viruses, the initial concentration and atomization volume of the virus droplets, the size of nebulizer nozzle (can affect the size and living conditions of the droplets), and the sampling methods and exposure time, all these investigators analyzed the survival of aerosolized viruses by changing the temperature and RH parameters, so the results have scientific value. Table 2 shows the major features of these representative studies.
Figure 3 representatively shows the experimental results under four working conditions, in where the RH is controlled at comfortable $(\sim 50 \% \mathrm{RH})$ laboratory conditions. Because different exposure period affects the survival rate of viruses, experiments that have similar exposure time (20-23 h) are selected for the comparative analysis. It can be seen that at a range of RHs, the relative survival rate of aerosolized viruses decreases significantly with increase of temperature. Additionally, when the temperature is above $25^{\circ} \mathrm{C}$, most viruses have no viability. Similarly, these findings are because high temperature increases the evaporation of atomized droplets and deteriorates the living conditions of aerosolized virus, resulting in virus inactivation.

Figure 4 presents the experimental results from four studies, with the temperature controlled at a comfortable laboratory environment $\left(19-25{ }^{\circ} \mathrm{C}\right)$ level and these results were summarized according to the different exposure times. Figure 4 (a) shows the influence of RH on the survival of aerosolized viruses with an exposure period of $1 \mathrm{~h}$. It was found that (1) virus survival in droplets and aerosols as a function of RH showed a U-shaped relationship with reduced viability at medium RHs ( 55\%) and increased viability at low and extremely high RHs. It indicates that controlling $\mathrm{RH}$ at a medium level in a specific space is beneficial to inhibit the viral viability in the air. (2) In the range of intermediate RHs, some viruses had a monotonic decrease in viability with increasing $\mathrm{RH}$ while other viruses had an increase in viability. It may be because the exposure time was too short to achieve sufficient virus inactivation, or because the $\mathrm{RH}$ affects droplet physics and chemistry.

Figure 4 (b) shows the effects of RH on the survival of aerosolized viruses exposed for $20 \mathrm{~h}$. It was found that (1) the viruses had a distinct survival minimum at median $\mathrm{RH}$, similar to the exposure results for $1 \mathrm{~h}$. (2) However, compared with Fig. 4(a), the viability of the same virus was different at different exposure periods, and the relative survival rate decreased more significantly in a longer exposure period. (3) The MNV and poliomyelitis viruses can maintain a high relative survival rate after $20 \mathrm{~h}$ exposure. For the high survival rate of MNV, it may be because the virus was experimented as a liquid film on the glass coupons, which compared to the atomized droplets with smaller particle size, had less efficient contact with the air and subsequently a slower affected rate. For the poliomyelitis virus, it may because of its strong viability in the nature. To conclude, virus survival in the air is significantly affected by the length of exposure time. Additionally, the results indicate a common rule that viruses survive better at intermediate RH, but with individual differences that may be affected by the limited RH operational condition. 


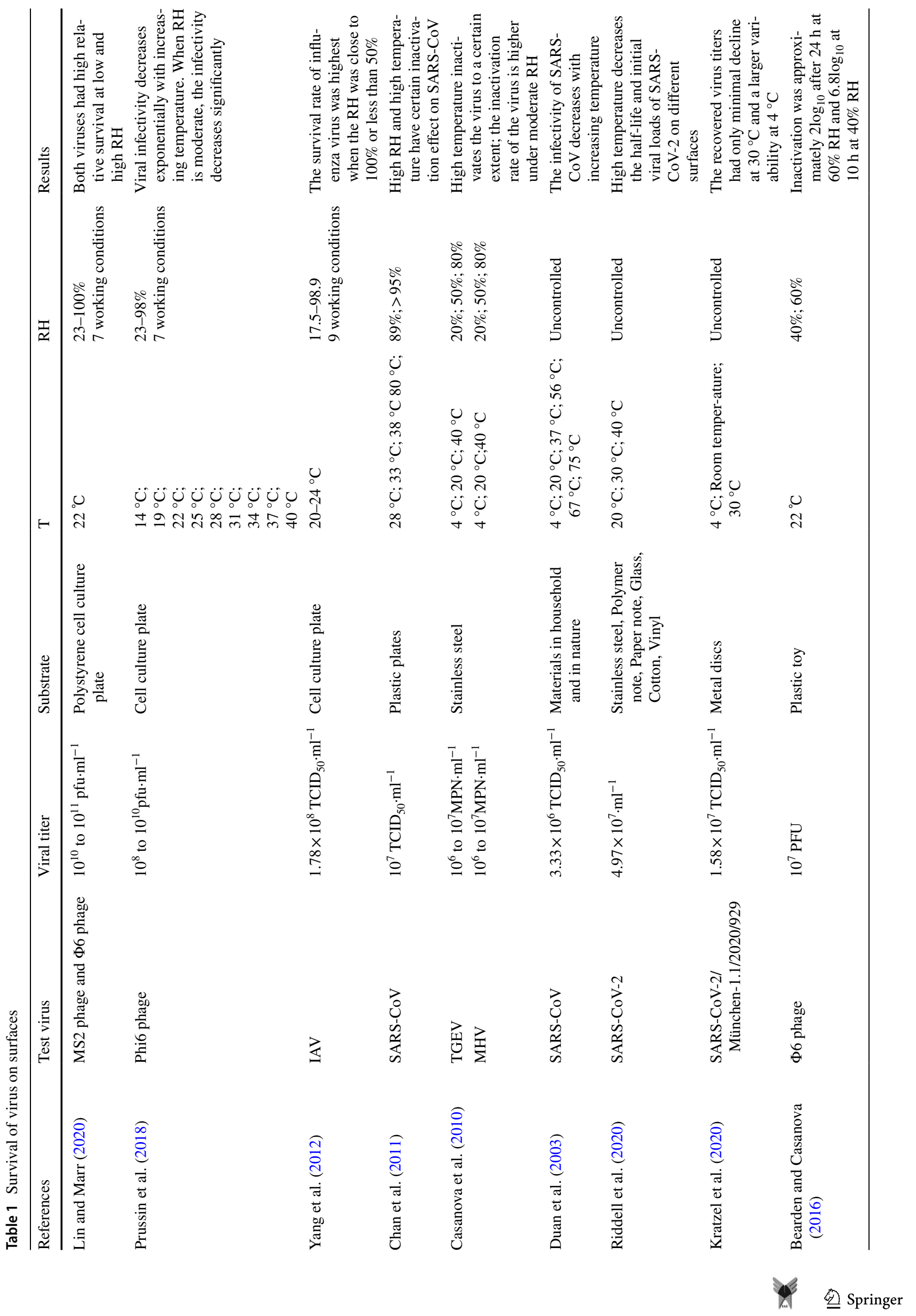




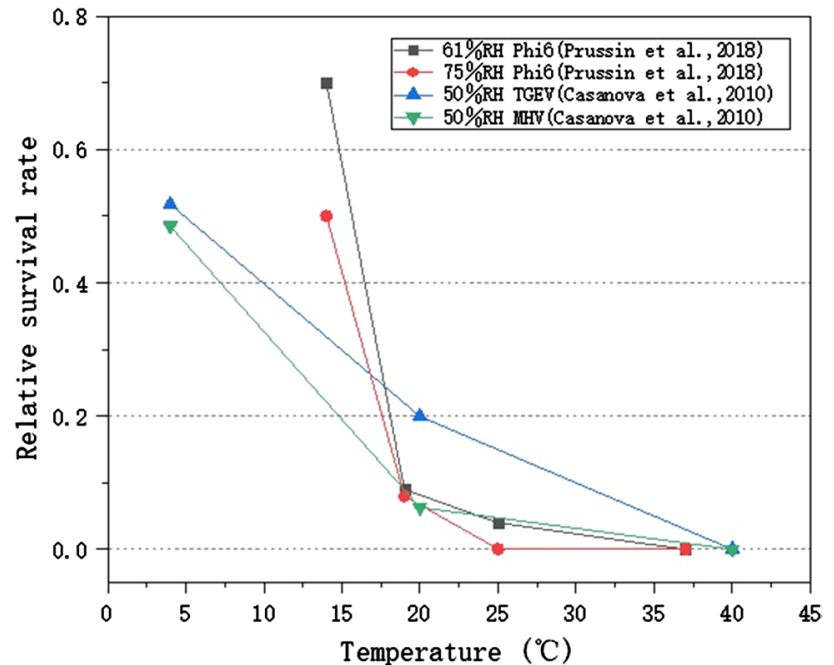

Fig. 1 Ambient temperature affects the survival of viruses on surfaces

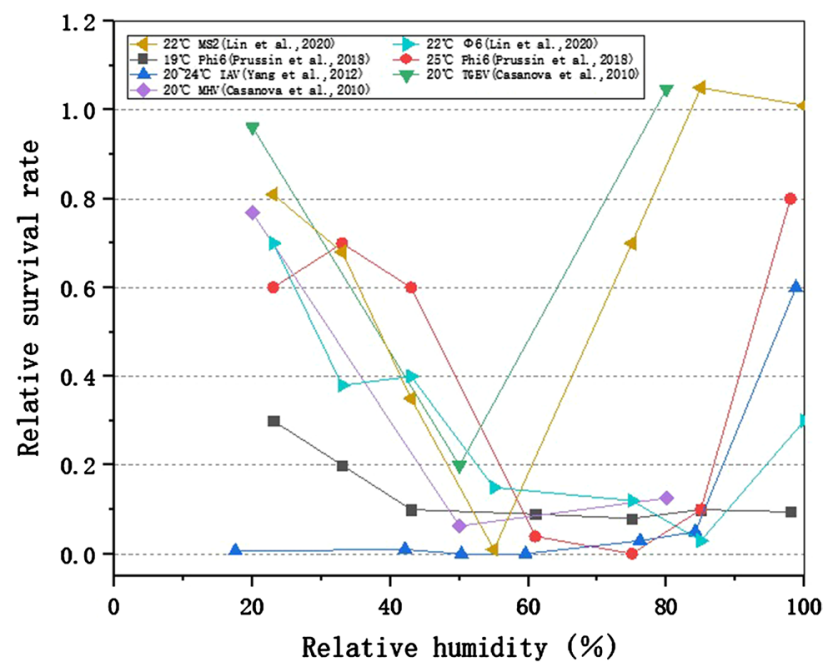

Fig. $2 \mathrm{RH}$ affects the survival of viruses on surfaces

\section{Effects of temperature and RH on virus infectivity in a restricted space}

As people spend over $90 \%$ of their time indoors (Klepeis et al. 2001), it is likely that virus transmission among humans occurs mainly in a restricted space. Viruses enter into specific environments in droplets or sputum, and the amount and activity of the active viruses have a significant impact on the risk of infection of susceptible individuals (Lindsley et al. 2012; Mao et al. 2020). However, to simulate the influence of temperature and humidity on virus transmission between the infected and susceptible individuals in a restricted space, only animal experiments can be used.

Susceptible people are mainly infected by infected patients or asymptomatic people though activities including speaking, breathing, coughing, and sneezing. They inhale the poisonous droplets that are exhaled by infected individuals through close contact and other behavior. Therefore, animal experiments are generally carried out in two ways: one is to make unaffected animals continuously exposed to large amounts of aerosolized viruses, simulating the special condition of droplet infection; the other is to make the animals contact exposed animals after inoculation, simulating the infection among persons through various contact methods. If other conditions are fixed, the corresponding influence can be identified by changing the temperature or $\mathrm{RH}$ and comparing the differences in infection rate or death rate under different conditions. Table 3 shows the species of experimental viruses, experimental animal, and infection method, as well as the range of temperature and $\mathrm{RH}$ and the main results. It can be seen from the table that although different studies have adopted various kinds of viruses and experimental animals and different ways of virus inoculation, they are all aimed at the specific objects of studying the influence of changing the temperature and $\mathrm{RH}$ parameters on the transmission and infectivity of viruses among animals in a restricted space.

A systematic review of the persistence of the influenza virus concluded that temperature, over an environmentally relevant range, is an important indicator of persistence across all environmental matrices considered, including air, water and soil (Irwin et al. 2011). Figure 5 shows the variation of the infection rate of exposed animals at low RH (35\%), medium RH (50\%) and high RH (80\%), which is affected by ambient temperature. It indicates that the infectivity of viruses is maximal at low temperature and low RH. At medium RH (50\%), the transmission efficiency of viruses is inversely correlated with temperature. Compared to viral infectivity at low temperature, those at room temperature largely decreased, and reduced to 0 at high temperature. Similarly, in humid environments (high RH), virus transmission was maximal at low temperature, and minimal at room temperature and high temperature. As a result, it can be seen that at a certain $\mathrm{RH}$, the infection rate of the susceptible animals is the highest at low temperature and low humidity, meanwhile, with the increase of temperature, the infectivity of the viruses generally shows a downward trend. At the same time, when the temperature is $30{ }^{\circ} \mathrm{C}$, the transmission of virus among animals is blocked, and the risk of infection of susceptible individuals is low.

Compared to the effect of temperature, the influence of $\mathrm{RH}$ on viral infectivity in animal models is more complex. From Fig. 6, it can be seen that viral infectivity and transmission efficiency decrease with the increase of $\mathrm{RH}$ at low temperature $\left(5^{\circ} \mathrm{C}\right)$. In addition, as high temperature can effectively block aerosol transmission of viruses, at $30{ }^{\circ} \mathrm{C}$ and all RHs tested, no infection was observed among animals through cage-to-cage contact. Moreover, under the relatively 
Table 2 Survival of aerosolized virus in the air

\begin{tabular}{|c|c|c|c|c|c|c|}
\hline References & Test virus & Initial concentration & $\begin{array}{l}\text { Aerosolization } \\
\text { space }\end{array}$ & $\mathrm{T}$ & RH & Results \\
\hline $\begin{array}{l}\text { Lin and Marr } \\
\text { (2020) }\end{array}$ & $\begin{array}{l}\text { MS2 phage and } \Phi 6 \\
\text { phage }\end{array}$ & $10^{10}$ to $10^{11} \mathrm{pfu} \cdot \mathrm{ml}^{-1}$ & $\begin{array}{l}27 \mathrm{~L} \text { aluminum } \\
\text { rotating drum }\end{array}$ & $22^{\circ} \mathrm{C}$ & $\begin{array}{l}23-100 \% \\
7 \text { working condi- } \\
\text { tions }\end{array}$ & $\begin{array}{l}\text { Viruses survived well } \\
\text { in RHs below } 33 \% \\
\text { and } 100 \%\end{array}$ \\
\hline \multirow{2}{*}{$\begin{array}{l}\text { Pyankov et al. } \\
\text { (2018) }\end{array}$} & \multirow[t]{2}{*}{ MERS-CoV } & \multirow[t]{2}{*}{$6.1 \pm 0.23 \mathrm{lg} \cdot \mathrm{ml}^{-1}$} & \multirow{2}{*}{$\begin{array}{l}\text { Rotating aerosol } \\
\text { chamber }\end{array}$} & $25^{\circ} \mathrm{C}$ & $79 \%$ & \multirow{2}{*}{$\begin{array}{l}\text { In hot, dry air, the } \\
\text { virus decays more } \\
\text { strongly }\end{array}$} \\
\hline & & & & $38^{\circ} \mathrm{C}$ & $24 \%$ & \\
\hline \multirow[t]{2}{*}{$\begin{array}{l}\text { de la Noue et al. } \\
\text { (2014) }\end{array}$} & \multirow[t]{2}{*}{ MNV } & \multirow[t]{2}{*}{$10^{6.2} \mathrm{pfu} \cdot \mathrm{ml}^{-1}$} & \multirow[t]{2}{*}{$\begin{array}{l}\text { Sealed aerosoliza- } \\
\text { tion boxes }\end{array}$} & $25^{\circ} \mathrm{C}$ & $\begin{array}{l}10-100 \% \\
5 \text { working condi- } \\
\text { tions }\end{array}$ & $\begin{array}{l}\text { Moderate RH facili- } \\
\text { tates viral inactiva- } \\
\text { tion and reduces } \\
\text { viral infectivity }\end{array}$ \\
\hline & & & & $\begin{array}{l}9{ }^{\circ} \mathrm{C} \\
25^{\circ} \mathrm{C}\end{array}$ & $\begin{array}{l}10-100 \% \\
5 \text { working condi- } \\
\text { tions }\end{array}$ & $\begin{array}{l}\text { Low temperature is } \\
\text { more suitable for } \\
\text { virus survival }\end{array}$ \\
\hline \multirow[t]{2}{*}{ Noti et al. (2013) } & \multirow[t]{2}{*}{ H1N1 } & \multirow[t]{2}{*}{$\begin{array}{l}4.5 \times 10^{3} \text { total } \\
\text { virus } 1^{-1}\end{array}$} & \multirow[t]{2}{*}{$\begin{array}{l}23 \mathrm{~m}^{3} \text { aerosolization } \\
\text { chamber }\end{array}$} & $20^{\circ} \mathrm{C}$ & $\begin{array}{l}7-73 \% \\
7 \text { working condi- } \\
\text { tions }\end{array}$ & $\begin{array}{l}\text { High RH reduces } \\
\text { the infectivity of } \\
\text { influenza viruses }\end{array}$ \\
\hline & & & & $20^{\circ} \mathrm{C}$ & $20 \%, 45 \%$ & $\begin{array}{l}\text { At moderate humid- } \\
\text { ity, viruses in } \\
\text { aerosols rapidly } \\
\text { lose infectivity after } \\
\text { coughing }\end{array}$ \\
\hline $\begin{array}{l}\text { van Doremalen, } \\
\text { Bushmaker, and } \\
\text { Munster (2013) }\end{array}$ & MERS-CoV & $10^{6} \mathrm{TCID}_{50} \cdot \mathrm{ml}^{-1}$ & $\begin{array}{l}\text { An aerosolization } \\
\text { chamber }\end{array}$ & $20^{\circ} \mathrm{C}$ & $40 \%, 70 \%$ & $\begin{array}{l}\text { MERS-CoV virus } \\
\text { aerosols are very } \\
\text { stable at low rela- } \\
\text { tive humidity }\end{array}$ \\
\hline Zhao et al. (2011) & Gumbro & $\begin{array}{l}6 \text { to } 7 \log _{10} \\
\text { EID }_{50} \cdot \mathrm{ml}^{-1}\end{array}$ & $\begin{array}{l}1.4 \mathrm{~m}^{3} \text { aerosoliza- } \\
\text { tion chamber }\end{array}$ & $\begin{array}{l}10^{\circ} \mathrm{C} \\
20^{\circ} \mathrm{C} \\
30^{\circ} \mathrm{C}\end{array}$ & $40 \%, 70 \%$ & $\begin{array}{l}\text { Long-range transmis- } \\
\text { sion of airborne } \\
\text { viruses is more } \\
\text { likely at } 20^{\circ} \mathrm{C} \text { than } \\
\text { at } 10^{\circ} \mathrm{C} \text { or } 30^{\circ} \mathrm{C}\end{array}$ \\
\hline \multirow[t]{4}{*}{ Harper (1961) } & Vaccinia virus & $5 \times 10^{7} \mathrm{pfu} \cdot \mathrm{ml}^{-1}$ & \multirow[t]{4}{*}{$\begin{array}{l}\text { 75L rotating stain- } \\
\text { less steel drum }\end{array}$} & $\begin{array}{l}\text { (1) } 11{ }^{\circ} \mathrm{C} \\
\text { (2) } 22^{\circ} \mathrm{C} \\
\text { (3) } 32^{\circ} \mathrm{C}\end{array}$ & $\begin{array}{l}\text { (1) } 20 \%, 50 \%, 83 \% \text {; } \\
\text { (2) } 18 \%, 50 \%, 83 \% \text {; } \\
\text { (3) } 18 \%, 50 \%, 82 \%\end{array}$ & \multirow{4}{*}{$\begin{array}{l}\text { Most viruses survive } \\
\text { well at low tem- } \\
\text { peratures } \\
\text { The lower the rela- } \\
\text { tive humidity, the } \\
\text { better the survival } \\
\text { of most viruses, the } \\
\text { opposite is true for } \\
\text { poliovirus }\end{array}$} \\
\hline & Influenza virus & $\begin{array}{l}1 \times 10^{7} \\
\mathrm{MP}_{50} \cdot \mathrm{ml}^{-1}\end{array}$ & & $\begin{array}{l}\text { (1) } 7{ }^{\circ} \mathrm{C} \\
\text { (2) } 22{ }^{\circ} \mathrm{C} \\
\text { (3) } 32{ }^{\circ} \mathrm{C}\end{array}$ & $\begin{array}{l}\text { (1) } 24 \%, 51 \%, 82 \% \text {; } \\
\text { (2) } 21 \%, 35 \%, 50 \% \text {, } \\
65 \%, 81 \% \text {; } \\
\text { (3) } 30 \%, 50 \%, 81 \%\end{array}$ & \\
\hline & $\begin{array}{l}\text { Venezuelan equine } \\
\text { encephalom- } \\
\text { yelitis virus }\end{array}$ & $\begin{array}{l}1 \times 10^{10} \text { MIPLD } \\
{ }_{50} \cdot \mathrm{ml}^{-1}\end{array}$ & & $\begin{array}{l}\text { (1) } 9{ }^{\circ} \mathrm{C} \\
\text { (2) } 22{ }^{\circ} \mathrm{C} \\
\text { (3) } 32{ }^{\circ} \mathrm{C}\end{array}$ & $\begin{array}{l}\text { (1) } 19 \%, 48 \%, 86 \% \text {; } \\
\text { (2) } 21 \%, 50 \%, 82 \% \text {; } \\
\text { (3) } 19 \%, 48 \%, 83 \%\end{array}$ & \\
\hline & Poliomyeli-tis virus & $5 \times 10^{8} \mathrm{pfu} \cdot \mathrm{ml}^{-1}$ & & $22{ }^{\circ} \mathrm{C}$ & $\begin{array}{l}20.5 \% \\
35 \% \\
50 \% \\
65 \% \\
80 \%\end{array}$ & \\
\hline \multirow[t]{2}{*}{$\begin{array}{l}\text { Hemmes et al. } \\
\text { (1962) }\end{array}$} & Influenza virus & $\begin{array}{l}2 \times 10^{3} \text { to } 2 \times 10^{4} \\
\mathrm{ID}_{50} \cdot \mathrm{l}^{-1}\end{array}$ & \multirow[t]{2}{*}{$\begin{array}{l}4 \mathrm{~m}^{3} \text { aerosolization } \\
\text { chamber }\end{array}$} & $\begin{array}{l}10^{\circ} \mathrm{C} \\
20^{\circ} \mathrm{C} \\
30^{\circ} \mathrm{C}\end{array}$ & \multirow[t]{2}{*}{$<50 \% ;>50 \%$} & $\begin{array}{l}\text { Viral mortality } \\
\text { increases with rela- } \\
\text { tive humidity }\end{array}$ \\
\hline & Poliomyelitis virus & $2-8 \times 10^{7} \mathrm{pfu} \cdot \mathrm{ml}^{-1}$ & & & & $\begin{array}{l}\text { Viral mortality } \\
\text { decreases with } \\
\text { increasing relative } \\
\text { humidity }\end{array}$ \\
\hline
\end{tabular}


Table 2 (continued)

\begin{tabular}{|c|c|c|c|c|c|c|}
\hline References & Test virus & Initial concentration & $\begin{array}{l}\text { Aerosolization } \\
\text { space }\end{array}$ & $\mathrm{T}$ & RH & Results \\
\hline $\begin{array}{l}\text { Smither et al. } \\
\text { (2020) }\end{array}$ & $\begin{array}{l}\text { SARS-CoV-2 Eng- } \\
\text { land-2 }\end{array}$ & $1 \times 10^{6} \mathrm{TCID}_{50} \cdot \mathrm{ml}^{-1}$ & 40L Goldberg drum & $19-22{ }^{\circ} \mathrm{C}$ & $40-60 \% ; 68-88 \%$ & $\begin{array}{l}\text { In tissue culture } \\
\text { media, SARS- } \\
\text { CoV-2 England-2 } \\
\text { is more stable at } \\
\text { medium RH com- } \\
\text { pared to higher RH }\end{array}$ \\
\hline
\end{tabular}

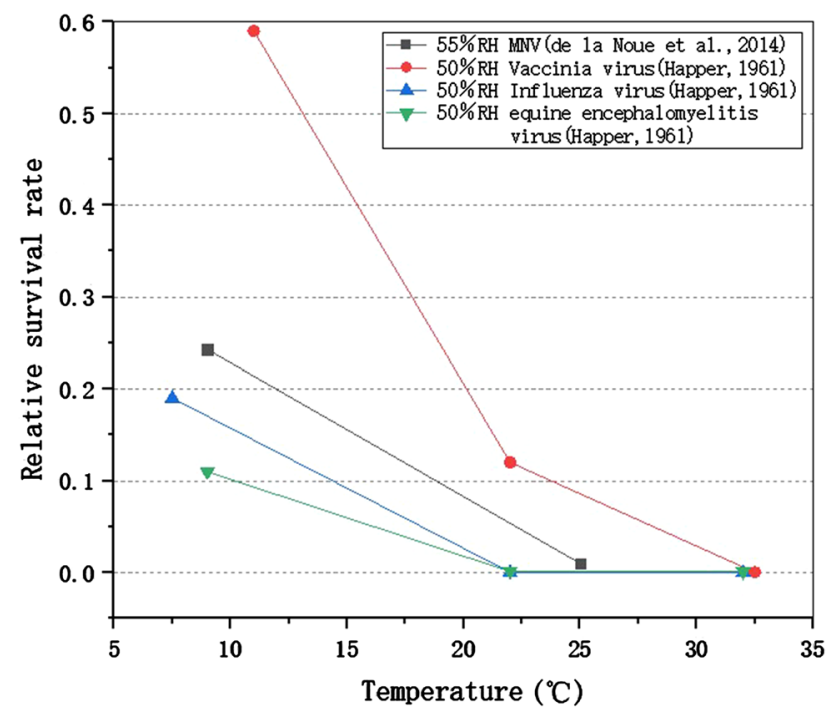

Fig. 3 Temperature affects the survival of aerosolized virus

comfortable temperature range of $20-23{ }^{\circ} \mathrm{C}$, although the experimental animal species, virus species and animal infection methods are different, the virus transmission as a function of RH has a U-shaped relationship with reduced infection rate at mid-range RHs ( $50 \%)$ and increased infection rate at low RH or high RH. It indicates that controlling RH at a medium level $(\sim 50 \%)$ is beneficial to reduce the infection rate and the threat of the virus to susceptible people in a restricted space.

\section{Environmental Implications for COVID-19}

Following the review of the influence of temperature and $\mathrm{RH}$ on virus survival and viral infectivity among susceptible animals, it can be seen that the environment with low ambient temperature, low $\mathrm{RH}$ or high $\mathrm{RH}$ is beneficial to virus survival and transmission. It suggests that low temperature, low $\mathrm{RH}$, high $\mathrm{RH}$ or a combination may lead to the risk of epidemic spread. It provides valuable insights into the prevention and control of COVID-19. Firstly, when the temperature and humidity environment (seasonal change of outdoor climate parameters) cannot be

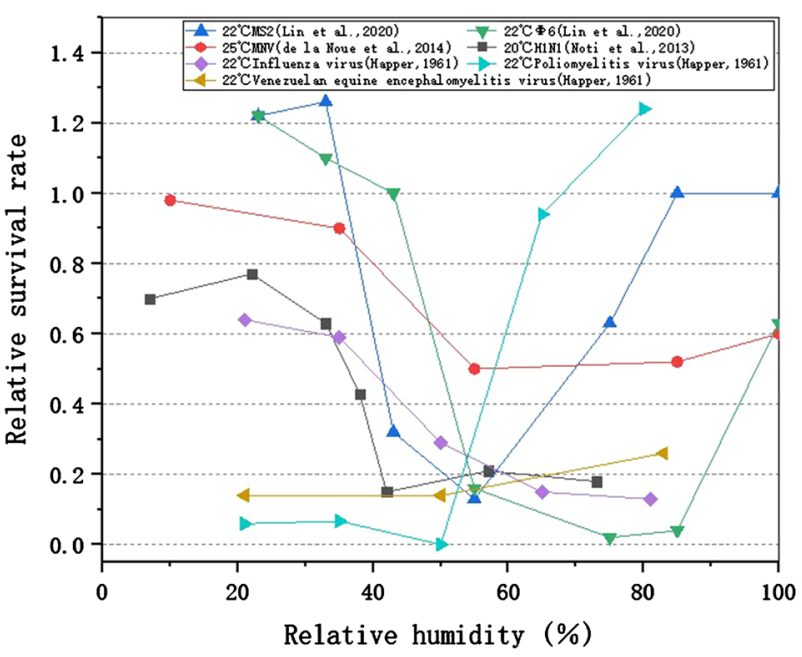

(a) Exposure for $1 \mathrm{~h}$

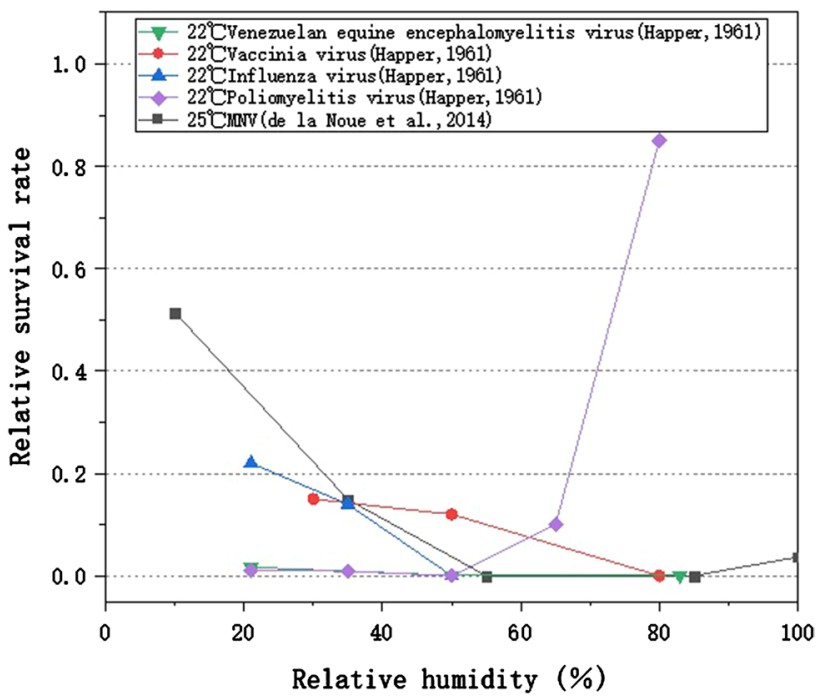

(b) Exposure for $20 \mathrm{~h}$

Fig. 4 RH affects the survival of aerosolized virus

controlled, if the future climate change in a specific region or city is known, it can alert people to the risk of epidemic spread. Secondly, indoor environments of all buildings on which human activities depend can be generally controlled, 
Table 3 Infectivity of virus in animal models

\begin{tabular}{|c|c|c|c|c|c|c|c|}
\hline References & Test virus & Viral titer & Animal(s) & Contact method & $\mathrm{T}$ & $\mathrm{RH}(\%)$ & Results \\
\hline \multirow[t]{8}{*}{ Gustin et al. (2015) } & \multirow[t]{4}{*}{ PN99 } & \multirow[t]{8}{*}{$10^{3.8}$ to $10^{5.5} \mathrm{pfu} \cdot \mathrm{ml}^{-1}$} & \multirow[t]{8}{*}{ Ferrets } & \multirow[t]{8}{*}{ Aerosolized virus } & $5^{\circ} \mathrm{C}$ & 70 & Infectivity $33.3 \%$ \\
\hline & & & & & $23^{\circ} \mathrm{C}$ & 30 & Infectivity $66.7 \%$ \\
\hline & & & & & & 50 & Infectivity $33.3 \%$ \\
\hline & & & & & & 70 & Infectivity $66.7 \%$ \\
\hline & \multirow[t]{4}{*}{ IN11 } & & & & $5^{\circ} \mathrm{C}$ & 70 & Infectivity $0 \%$ \\
\hline & & & & & $23^{\circ} \mathrm{C}$ & 30 & Infectivity $100 \%$ \\
\hline & & & & & & 50 & Infectivity $0 \%$ \\
\hline & & & & & & 70 & Infectivity $66.7 \%$ \\
\hline \multirow[t]{8}{*}{ Lowen et al. (2008) } & \multirow[t]{8}{*}{ PN99 } & \multirow[t]{8}{*}{$10^{3} \mathrm{pfu} \cdot \mathrm{ml}^{-1}$} & \multirow[t]{8}{*}{ Guinea pigs } & Cage to cage & $30^{\circ} \mathrm{C}$ & 20 & Infectivity $0 \%$ \\
\hline & & & & & & 50 & \\
\hline & & & & & & 65 & \\
\hline & & & & & & 80 & \\
\hline & & & & Housed in one cage & $30^{\circ} \mathrm{C}$ & 20 & Infectivity $100 \%$ \\
\hline & & & & & & 50 & Infectivity $100 \%$ \\
\hline & & & & & & 80 & Infectivity $75 \%$ \\
\hline & & & & & $20^{\circ} \mathrm{C}$ & 20 & Infectivity $100 \%$ \\
\hline \multirow[t]{10}{*}{ Lowen (2007) } & \multirow[t]{10}{*}{ PN99 } & \multirow[t]{10}{*}{$10^{3} \mathrm{pfu} \cdot \mathrm{ml}^{-1}$} & \multirow[t]{10}{*}{ Guinea pigs } & \multirow[t]{10}{*}{ Cage to cage } & $5^{\circ} \mathrm{C}$ & 35 & Infectivity $100 \%$ \\
\hline & & & & & & 50 & Infectivity $75-100 \%$ \\
\hline & & & & & & 65 & Infectivity $50 \%$ \\
\hline & & & & & & 80 & Infectivity $50 \%$ \\
\hline & & & & & $20^{\circ} \mathrm{C}$ & 20 & Infectivity $75-100 \%$ \\
\hline & & & & & & 35 & Infectivity $100 \%$ \\
\hline & & & & & & 50 & Infectivity $25 \%$ \\
\hline & & & & & & 65 & Infectivity $75 \%$ \\
\hline & & & & & & 80 & Infectivity $0 \%$ \\
\hline & & & & & $30^{\circ} \mathrm{C}$ & 35 & Infectivity $0 \%$ \\
\hline \multirow[t]{10}{*}{ Lester (1948) } & \multirow{10}{*}{$\begin{array}{c}\text { Influenza } \\
\text { A-PR8 } \\
\text { strain }\end{array}$} & \multirow[t]{10}{*}{$0.82-0.85 \mathrm{gm}$} & \multirow[t]{10}{*}{ Mice } & \multirow[t]{10}{*}{ aerosolized virus } & \multirow[t]{10}{*}{$23^{\circ} \mathrm{C}$} & 23 & Mortality $100 \%$ \\
\hline & & & & & & 30 & Mortality $100 \%$ \\
\hline & & & & & & 40 & Mortality $95 \%$ \\
\hline & & & & & & 45 & Mortality $22.5 \%$ \\
\hline & & & & & & 50 & Mortality $22.5 \%$ \\
\hline & & & & & & 55 & Mortality $22.5 \%$ \\
\hline & & & & & & 60 & Mortality $22.5 \%$ \\
\hline & & & & & & 65 & Mortality $42.5 \%$ \\
\hline & & & & & & 70 & Mortality $75 \%$ \\
\hline & & & & & & 80 & Mortality $100 \%$ \\
\hline
\end{tabular}

or at least partially controlled, so measures that are positive to block virus survival and reduce the infection among individuals should be considered when regulating indoor environments.

\section{Strategy for uncontrollable environment}

There are two kinds of situations for uncontrollable temperature and humidity environments. The first factor is the outdoor natural temperature and humidity, which is mainly affected by the geographical location, altitude, solar radiation and other factors, changing seasonally over the whole year. The temperature and humidity changes can be used to predict the ability of virus survival and the infective risk of susceptible individuals in such environments in advance, and can provide prevention and control strategies for the public and their outdoor activities. For example, at the end of winter and early spring, the temperature rises in many cities. However, there may also be a "cold in late spring" climate in some cities in China, which needs to be paid attention to in the case of repeated community outbreaks of COVID-19. On the other hand, in some areas in China, there will be a regular "plum rain" season between spring and summer, and the air humidity largely increases, which may also create favorable climate conditions for virus survival and susceptible individual infection. 


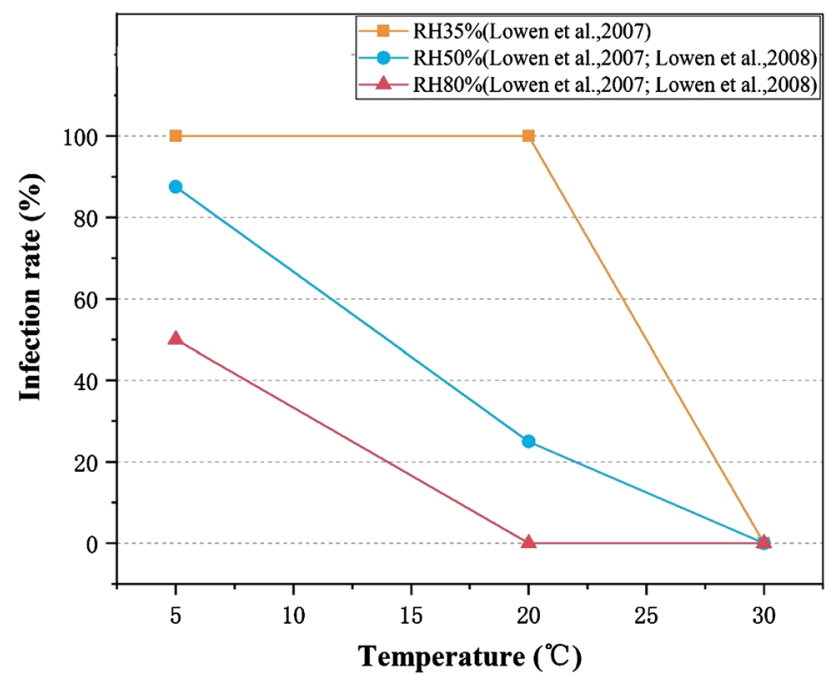

Fig. 5 Temperature affects the infectivity of virus in animal models

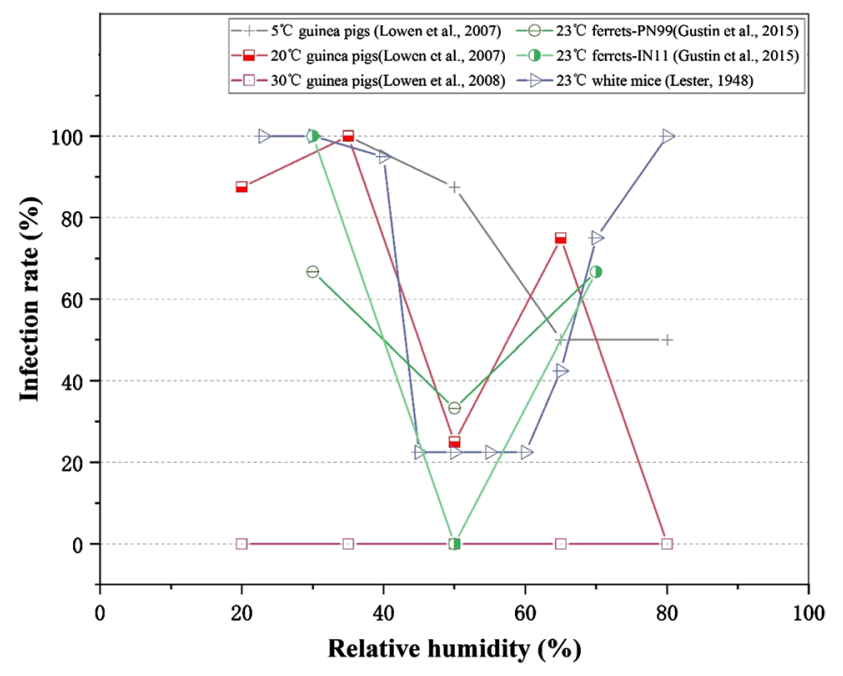

Fig. 6 RH affects the infectivity of virus in animal models

Secondly, for those buildings without central heating, it is hard to control indoor environments. During the spread of COVID-19, it would be better to control the indoor temperature and $\mathrm{RH}$ at a level that is harmful to virus survival and transmission. There is a wide range of areas around the world that do not pay special attention to the regulation of indoor environments. For example, the hot summer and cold winter areas in China involve a population of 400-500 million, where the average temperature in winter months is 2-9 ${ }^{\circ} \mathrm{C}$, and the RH is $70-90 \%$ (Fu 2020). In these areas, most of the residential buildings or some public buildings do not have central heating, so the temperature and humidity of indoors and outdoors are similar in winter (Fu 2020). For a small number of buildings that can be heated (generally using air source heat pump), they have no humidification equipment. When the indoor temperature is heated to $18-20$ ${ }^{\circ} \mathrm{C}$, the indoor RH will be reduced to $20-30 \%$. These indoor conditions are suitable for virus stability and virus transmission among people. Because the coupling of outdoor and indoor environmental conditions is conducive to virus survival, transmission and infection, it may have caused the spread of COVID-19 in Wuhan. Therefore, during a COVID19 outbreak, buildings without central heating or air conditioning are recommended to increase their indoor temperature to a comfortable level by using local heating systems, which is beneficial to virus inactivation. On the other hand, for buildings with decentralized heating, it is necessary to turn on the heating equipment and employ humidification (electric humidifiers, simple humidifiers, etc.) to keep the indoor RH at a comfortable level (RH $40-50 \%)$, or at least not too dry.

\section{Strategy for controllable environment}

On the contrary, indoor environments of all buildings can be controlled, or at least partially controlled. To date, most of the activities are carried out indoors, and the means of regulating indoor environments have improved (Klepeis et al. 2001). However, as virus transmission among humans occurs mainly indoors, the relationship between the risk of individual infection and the operation of heating, airconditioning and ventilation systems is controversial. The current prevention and control guidelines also lack information for the control of indoor temperature and RH. Health departments in many countries have made it clear that office buildings and public buildings need to operate air conditioning systems (Wilson 2020; Coolingpost 2020), but they have not provided adjustment suggestions for the setting of the heating or cooling system. As discussed above, a series of experiments on virus survival and animal infection indicates that a certain range of temperature and RHs are not conducive to the survival and transmission of virus. Therefore, the following prevention and control strategies can be suggested for indoor environmental control. (1) For residential buildings with adjustable indoor temperature and RHs, residents should be encouraged to turn on household heating equipment in winter and try to improve indoor temperature as much as possible, such as $18-20{ }^{\circ} \mathrm{C}$, which can reduce virus transmission among susceptible people. Recommendations for residents not to use air conditioning and heating equipment lack scientific basis. (2) As medium RH $(\sim 50 \%)$ can significantly reduce virus transmission among the susceptible people, residents are recommended to use humidifiers and dehumidifiers to make the indoor RH close to this range, which is beneficial to virus prevention and control. (3) For office buildings, commercial buildings and public buildings, the air conditioning and heating system can be normally operated, and indoor environments can be 
controlled at $18-22{ }^{\circ} \mathrm{C}$ and medium RH ( 50\%) by adjusting the set value of the heating or cooling system. (4) The indoor ventilation of residential buildings should not be excessive, and the operation of ventilation system should not be emphasized groundlessly for public buildings. However, the current strategy of building ventilation ignores the effect of indoor temperature and $\mathrm{RH}$ on virus transmission and infectivity among susceptible people. One-sided guidance to strengthen building ventilation or all fresh air can reduce the virus concentration in the air, but because the existing air conditioning and heating equipment system cannot bear the load, it will inevitably lead to a sharp decrease of indoor temperature, which is positive to virus survival and transmission, and may not be conducive to prevent and control the spread of COVID-19. (5) As it has been discussed in the aerosolized virus survival experiments, the number of viruses in droplets is $10^{3}$ to $10^{10} \mathrm{pfu} / \mathrm{ml}$, equilibrated to that in the oral swabs, nose swabs and throat swabs of the SARSCoV-2 infected patients (Pan et al. 2020; Zou et al. 2020; To et al. 2020). When the virus suspension is aerosolized into a rotating drum, virus inactivation rates are in the order of $10^{2}$ to $10^{4}$ even if samples are collected immediately (in $2 \mathrm{~min}$ ), indicating that the most of the viruses have died (Zhao et al. 2011). When viruses leave the host, their living environments deteriorate rapidly in a few milliseconds because of water evaporation, salt concentration, and acid-base balance destruction. It is indirectly proven that the major risk of droplet transmission occurs when droplets leave the host, and the shorter time it is, the greater the risk. Therefore, if there is a potential infected person in a room, the most effective method of surveillance and containment is to keep social distancing, and wear a mask, which is simple and easy and has the lowest social cost (Cheng and Zou 2020; Leung et al. 2020; Wei et al. 2021). For viruses that have been floating in the air for a long time with low vitality, it is advisable to regulate indoor environments according to the influence of temperature and $\mathrm{RH}$ on virus survival and spread.

\section{Implications for COVID-19 seasonality}

A series of studies have proven that temperature and $\mathrm{RH}$ have influence on the seasonality of influenza and other respiratory diseases (Davis et al. 2012; Otter et al. 2016; Oliveiros et al. 2020; Chen et al. 2020; Ma et al. 2020; Wang et al. 2021). Previous studies have shown that wintertime climate and host behavior can favor the influenza transmission (Shaman et al. 2011; Chattopadhyay et al. 2018) and other human coronaviruses (Killerby et al. 2018; Neher et al. 2020). SARS-CoV-2 survived the longest on surfaces under winter conditions, with a survival post-contamination on most surfaces up to 21 days, followed by spring/fall conditions, with a survival up to 7 days (Ahlawat et al. 2020). Infectious virus was isolated up to 4 days post-contamination under indoor conditions, whereas no infectious virus was found at 3 days post-contamination under summer conditions (Kwon et al. 2021).

Virus survival and transmission is sensitive to outdoor and indoor temperature and humidity, as well as the change of susceptible population in a restricted space. While the outdoor temperature and humidity cannot be controlled artificially, a healthy and comfortable indoor environment can be created by adjusting indoor temperature and humidity. It is a positive measure to reduce the indoor infection risk of susceptible groups. Additionally, other preventive measures including wearing masks should be considered to decrease their risk of outdoor infection. Therefore, virus survival and virus spread within and between human populations can be effectively inhibited.

\section{Conclusion}

Based on the experimental evidence of virus inactivation, this paper revealed the influence of ambient temperature and RH on virus survival and infectivity, discussed the environmental prevention strategies for COVID-19 in different situations, and identified the scientific methods of manually controlling indoor temperature and $\mathrm{RH}$ parameters during the epidemic period. The main conclusions are as follows:

Firstly, the survival rate decreases with the increase of temperature, and virus inactivation generally occurs at $25-30{ }^{\circ} \mathrm{C}$. In addition, viruses in the air and on surfaces can be effectively reduced at RHs of 50-70\%. Therefore, environmental conditions with low temperature and low $\mathrm{RH}$, or with low temperature are positive to virus survival. It also suggests that human coronaviruses, including SARS-CoV-2, have shown to display strong winter seasonality.

Secondly, increased temperature and intermediate $\mathrm{RH}$ $(\sim 50 \%)$ has negative effects on virus infection and transmission among animals, indicating that it can reduce the threat of viruses to susceptible populations in a restricted space. Based on research findings, for future scenarios, setting a moderate RH standard of 50\% for indoor environments will not only reduce the impact of COVID-19, but it will also reduce the impact of further viral outbreaks, both seasonal and novel.

Finally, as low temperature and dry environment are conducive to the survival and transmission of viruses, in winter, it is necessary to focus on the role of indoor air on disease transmission and resident health. Superabundant ventilatory volume in winter or in the heating period can lead to low indoor temperature or dry indoor air, which will increase the risk of infection of the susceptible people. Therefore, in order to curb the outbreak of 
COVID-19, it is necessary to scientifically adjust indoor environments according to the influence of temperature and RH on virus survival and transmission. For a controllable indoor environment, the ventilation strategy should not be emphasized unilaterally, but to encourage residents to keep indoor environments at $18-20{ }^{\circ} \mathrm{C}$ and medium RH ( $\sim 50 \%)$ by the air-conditioning system and humidification equipment. For the uncontrollable outdoor temperature and humidity, people can be alerted so as to realize the risk of epidemic spread according to the change of climate conditions, and other precautions such as wearing masks and maintaining social distancing are also necessary.

Acknowledgements This work was supported by the National Natural Science Foundation of China (51778382) with the grant of RMB 710,000.00, and the National Key R\&D Program of China (2016YFC0700400) with the Grant of RMB 3,960,000.00.

\section{Declarations}

Conflict of interest The authors declare that they have no known competing financial interests or personal relationships that could have appeared to influence the work reported in this paper.

\section{References}

Ahlawat A, Wiedensohler A, Mishra S (2020) An overview on the role of relative humidity in airborne transmission of SARS-CoV-2 in indoor environments. Aerosol Air Qual Res 20:1856-1961. https://doi.org/10.4209/aaqr.2020.06.0302

Al-H MA, Ma'mon M, Walhan A, Engku NE, Manali HM, Dina M, ChanYY IZ, Alias JJ, Khalid F, Jean-Luc S, Vuk U, Hiroshi Y, Rohimah M (2021) COVID-19 infection and nanomedicine applications for development of vaccines and therapeutics: an overview and future perspectives based on polymersomes. Eur J Pharmacol. https://doi.org/10.1016/j.ejphar.2021.173930

Alvarez-Ramirez J, Monica M (2020) Role of meteorological temperature and relative humidity in the January-February 2020 propagation of 2019-nCoV in Wuhan. China Medrxiv. https://doi.org/10. 1101/2020.03.19.20039164

Asadi S, Bouvier N, Wexler AS, Ristenpart ED (2020) The coronavirus pandemic and aerosols: does COVID-19 transmit via expiratory particles? Aerosol Sci Technol. https://doi.org/10.1080/02786826. 2020.1749229

Bashir MF, Benjiang M, Bilal BK, Muhammad AB, Duojiao T, Madiha B (2020) Correlation between climate indicators and COVID-19 pandemic in New York, USA. Sci Total Environ. https://doi.org/ 10.1016/j.scitotenv.2020.138835

Bearden RL, Casanova LM (2016) Survival of an enveloped virus on toys. Pediatric Infect Dis J 35(8):923-924. https://doi.org/10. 1097/INF.0000000000001193

Bukhari Q, Jameel Y (2020) Will coronavirus pandemic diminish by summer? SSRN Electron J. https://doi.org/10.2139/ssrn. 3556998

Casanova LM, Soyoung J, William AR, David JW, Mark DS (2010) Effects of air temperature and relative humidity on coronavirus survival on surfaces. Appl Environ Microbiol 76:2712-2717. https://doi.org/10.1128/AEM.02291-09

Chan KH, Peiris JSM, Lam SY, Poon LM, Yuen KY, Seto WH (2011) The effects of temperature and relative humidity on the viability of the SARS coronavirus. Adv Virol. https://doi.org/10.1155/ 2011/734690

Chan KH, Sridhar S, Zhang R, Chu H, Fung YF, Chan G, Chan JF, To KW, Hung FN, Cheng CC, Yuen KY (2020) Factors affecting stability and infectivity of SARS-CoV-2. J Hosp Infect 106:226-231. https://doi.org/10.1016/j.jhin.2020.07.009

Chattopadhyay I, Kiciman E, Elliott JW, Shaman JL, Rzhetsky A (2018) Conjunction of factors triggering waves of seasonal influenza. eLife. https://doi.org/10.7554/eLife.30756

Chen B, Liang H, Yuan X, HuY XuM, Zhao Y, Zhang B, Tian F, Zhu X (2020) Roles of meteorological conditions in COVID-19 transmission on a worldwide scale. medRxiv. https://doi.org/10. $1101 / 2020.03 .16 .20037168$

Cheng K, Zou C (2020) Biomedical infophysical models of filtering ghost airflows by wearing masks and maintaining social distancing to prevent COVID-19 and reopen all systems after shutdowns (Lockdowns). J Public Health Int 2(4):26-39. https:// doi.org/10.14302/issn.2641-4538.jphi-20-3426

Chitrakar B, Min Z, Bhesh B (2021) Improvement strategies of food supply chain through novel food processing technologies during COVID-19 pandemic. Food Control. https://doi.org/10.1016/j. foodcont.2021.108010

Coolingpost (2020) No evidence that AC is spreading coronavirus. https://www.coolingpost.com/uk-news/no-evidence-that-ac-isspreading-coronavirus/. Accessed 5 May 2020

Dalziel BD, Stephen K, Gog JR, CecileV BON, Metcalf CJE, Grenfell BT (2018) Urbanization and humidity shape the intensity of influenza epidemics in US cities. Science 362:75-79. https:// doi.org/10.1126/science.aat6030

Davis R, Rossier C, Kyle B (2012) The impact of weather on influenza and pneumonia mortality in New York City, 1975-2002: a retrospective study. PLoS ONE. https://doi.org/10.1371/journ al.pone.0034091

de la Noue AC, Estienney M, Aho S, Perrier-Cornet JM, de Rougemont A, Pothier P, Gervais P, Belliot G (2014) Absolute humidity influences the seasonal persistence and infectivity of human norovirus. Appl Environ Microbiol 80(23):7196-7205. https:// doi.org/10.1128/AEM.01871-14

Duan SM, Zhao XS, Wen RF, Huang JJ, Pi GH, Zhang SX, Han J, Bi SL, Ruan L, Dong XP (2003) Stability of SARS coronavirus in human specimens and environment and its sensitivity to heating and UV irradiation. Biomed Environ Sci 16:246-255

Dos S, Wagner G (2021) Impact of virus genetic variability and host immunity for the success of COVID-19 vaccines. Biomed Pharmacother 136:111272-111372. https://doi.org/10.1016/j. biopha.2021.111272

Fu X, Ding Y (2020) Re-understanding of HVAC climate characteristics in hot summer and cold winter zone. HV\&AC 50:1-6 ((in Chinese))

Gaunt ER, Hardie A, Claas EC, Simmonds P, Templeton KE (2010) Epidemiology and clinical presentations of the four human coronaviruses 229E, HKU1, NL63, and OC43 detected over 3 years using a novel multiplex real-time PCR method. J Clin Microbiol 48:2940-2947. https://doi.org/10.1128/JCM.00636-10

Glied S (2021) Strategy drives implementation: COVID vaccination in Israel. Israel J Health Policy Res. https://doi.org/10.1186/ s13584-021-00445-1

Guo L, Yang Z, Guo L, Chen L, Cheng Z, Li Z, Long ES (2021) Study on the decay characteristics and transmission risk of respiratory viruses on the surface of objects. Environ Res. https:// doi.org/10.1016/j.envres.2021.110716 
Gustin KM, Belser JA, Veguilla V, Hui Z, Katz JM, Tumpey TM, Maines TR (2015) Environmental conditions affect exhalation of $\mathrm{H} 3 \mathrm{~N} 2$ seasonal and variant influenza viruses and respiratory droplet transmission in ferrets. PLoS ONE. https://doi.org/10. 1371/journal.pone.0125874

Hadei M, Hopke PK, Jonidi A, Shahsavani A (2020) A letter about the airborne transmission of SARS-CoV-2 based on the current evidence. Aerosol Air Qual Res. 5:10

Harper GJ (1961) Airborne micro-organisms: survival tests with four viruses. J Hygiene. https://doi.org/10.2307/3861212

Hemmes JH, Kool SM, Winkler KC (1962) Virus survival as a seasonal factor in influenza and poliomyelitis. Antonie Van Leeuwenhoek J Microbiol Serol. https://doi.org/10.1007/BF02538737

Hsiao TC, Chuang HC, Griffith SM, Chen SJ, Young LH (2020) COVID-19: an Aerosol's point of view from expiration to transmission to viral-mechanism. Aerosol Air Qual Res 20:905-910. https://doi.org/10.4209/aaqr.2020.04.0154

Huang C, Wang Y, Li X (2020) Clinical features of patients infected with 2019 novel coronavirus in Wuhan, China. Lancet. https://doi. org/10.1016/S0140-6736(20)30183-5

Ijaz MK, Brunner AH, Sattar SA, Nair RC, Johnson-Lussenburg CM (1985a) Survival characteristics of airborne human coronavirus 229E. J Gen Virol 66:2743-2748. https://doi.org/10.1099/ 0022-1317-66-12-2743

Ijaz MK, Sattar SA, Johnson-Lussenburg CM, Springthorpe VS (1985b) Comparison of the airborne survival of calf rotavirus and poliovirus type 1 (Sabin) aerosolized as a mixture. Appl Environ Microbiol 49:289-293. https://doi.org/10.1128/AEM.49.2.289293.1985

Irwin CK, Yoon KJ, Wang C, Hoff SJ, Zimmerman JJ, Denagamage T, O'Connor AM (2011) Using the systematic review methodology to evaluate factors that influence the persistence of influenza virus in environmental matrices. Appl Environ Microbiol 77:1049-1060. https://doi.org/10.1128/aem.02733-09

Kampf G, Todt D, Pfaender S, Steinmann E (2020) Persistence of coronaviruses on inanimate surfaces and their inactivation with biocidal agents. J Hosp Infect 104:246-251. https://doi.org/10. 1016/j.jhin.2020.01.022

Killerby ME, Biggs MH, Haynes A, Dahl M, Mustaquim D, Gerber S, Watson JT (2018) Human coronavirus circulation in the United States 2014-2017. J Clin Virol 101:52-56

Klepeis NE, Nelson WC, Ott WR, Robinson JP, Tsang AM, Switzer P, Behar JV, Hern SC, Engelmann WH (2001) The national human activity pattern survey (NHAPS): a resource for assessing exposure to environmental pollutants. J Expo Anal Environ Epidemiol 11:231-252. https://doi.org/10.1038/sj.jea.7500165

Kratzel A, Steiner S, Todt D, V'Kovski P, Pfaender S (2020) Temperature-dependent surface stability of SARS-CoV-2. J Infect 81:474-476. https://doi.org/10.1016/j.jinf.2020.05.074

Kumar M, Kuroda K, Patel AK, Padel N (2020) Decay of SARSCoV-2 RNA along the wastewater treatment outfitted with Upflow Anaerobic Sludge Blanket (UASB) system evaluated through two sample concentration techniques. Sci Total Environ. https://doi. org/10.1016/j.scitotenv.2020.142329

Kwon K, Park JI, Park YJ, Jung DM, Ryu KW, Lee JH (2020) Evidence of long-distance droplet transmission of SARS-CoV-2 by direct air flow in a restaurant in Korea. J Korean Med Sci. https://doi. org/10.3346/jkms.2020.35.e415

Kwon T, Gaudreault N, Richt J (2021) Environmental stability of SARS-CoV-2 on different types of surfaces under indoor and seasonal climate conditions. Pathogens. https://doi.org/10.3390/ pathogens 10020227

Lester W (1948) The influence of relative humidity on the infectivity of air-borne influenza A virus (PR8 Strain). J Exp Med 88(3):361368. https://doi.org/10.1016/0022-4804(81)90170-0
Leung NL, Chu DKW, Shiu EYC, Chan KH, Mcdevitt JJ, Hau BJP, Yen HL, Li Y, Ip DKM, Peiris JSM, Seto WH, Leung GM, Milton DK, Cowling BJ (2020) Respiratory virus shedding in exhaled breath and efficacy of face masks. Nat Med 26(6):676-680. https://doi. org/10.21203/rs.3.rs-16836/v1

Lin K, Marr LC (2020) Humidity-dependent decay of viruses, but not bacteria, in aerosols and droplets follows disinfection kinetics. Environ Sci Technol 54:1024-1032. https://doi.org/10.1021/acs. est.9b04959

Lindsley WG, Pearce TA, Hudnall JB, Davis KA, Davis SM, Fisher MA, Khakoo R, Palmer JE, Clark KE, Celik I (2012) Quantity and size distribution of cough-generated aerosol particles produced by influenza patients during and after illness. J Occup Environ Hyg 9(7):443-449. https://doi.org/10.1080/15459624.2012.684582

Liu Y, Ning Z, Chen Y, Guo M, Liu Y, Gali NK, Sun L, Duan Y, Cai J, Westerdahl D, Liu X, Ho KF, Kan H, Fu Q, Lan K (2020) Aerodynamic characteristics and RNA concentration of SARS-CoV-2 aerosol in Wuhan hospitals during COVID-19 Outbreak. bioRxiv. https://doi.org/10.1101/2020.03.08.982637

Lowen AC, Steel J, Mubareka S, Palese P (2007) Influenza virus ransmission is dependent on relative humidity and temperature. PLoS Pathog 3(10):1470-1476. https://doi.org/10.1371/journal. ppat.0030151

Lowen AC, Steel J, Mubareka S, Palese P (2008) High temperature (30 degrees C) blocks aerosol but not contact transmission of influenza virus. J Virol 82:5650-5652. https://doi.org/10.1128/ JVI.00325-08

Lu HZ (2020) Drug treatment options for the 2019-new coronavirus (2019-nCoV). Biosci Trends 14:69-71. https://doi.org/10.5582/ bst.2020.01020

Ma YL, Zhao Y, Liu J, He X, Wang B, Fu S, Yan J, Niu J, Zhou J, Luo B (2020) Effects of temperature variation and humidity on the death of COVID-19 in Wuhan, China. Sci Total Environ. https:// doi.org/10.1016/j.scitotenv.2020.138226

Mao N, An CK, Guo LY, Wang M, Guo L, Guo SR, Long ES (2020) Transmission risk of infectious droplets in physical spreading process at different times: a review. Build Environ. https://doi.org/10. 1016/j.buildenv.2020.107307

Marr LC, Tang J, Van Mullekom S, Lakdawala S (2019) Mechanistic insights into the effect of humidity on airborne influenza virus survival, transmission and incidence. J R Soc Interface. https:// doi.org/10.1098/rsif.2018.0298

Moe K, Harper GJ (1983) The effect of relative humidity and temperature on the survival of bovine rotavirus in aerosol. Adv Virol 76:211-216. https://doi.org/10.1007/BF01311105

Morawska L, Cao J (2020) Airborne transmission of SARS-CoV-2: the world should face the reality. Environ Int 139:105730. https://doi. org/10.1016/j.envint.2020.105730

Morawska L, Donald KM (2020) It is time to address airborne transmission of coronavirus disease 2019 (COVID-19). Clin Infect Dis 71:2311-2313. https://doi.org/10.1093/cid/ciaa939

National Academies of Sciences, Engineering, and Medicine (2020) Rapid expert consultation on the possibility of bioaerosol spread of SARS-CoV-2 for the COVID-19 pandemic (April 1, 2020). The National Academies Press, Washington, DC.

Neher RA, Dyrdak R, Druelle V, Hodcroft EB, Albert J (2020) Potential impact of seasonal forcing on a SARS-CoV-2 pandemic. Swiss Med Wkly. https://doi.org/10.4414/smw.2020.20224

Noti JD, Blachere FM, McMillen CM, Lindsley WG, Kashon ML, Slaughter DR, Beezhold DH (2013) High humidity leads to loss of infectious influenza virus from simulated coughs. PLoS ONE. https://doi.org/10.1371/journal.pone.0057485

Oliveiros B, Caramelo L, Ferreira NC, Caramelo F (2020) Role of temperature and humidity in the modulation of the doubling time of COVID-19 cases. MedRxiv Preprint. https://doi.org/10.1101/ 2020.03.05.20031872 
Otter JA, Donskey C, Yezli S, Douthwaite S, Goldenberg SD, Weber DJ (2016) Transmission of SARS and MERS coronaviruses and influenza virus in healthcare settings: the possible role of dry surface contamination. J Hosp Infect 92:235-250. https://doi.org/10. 1016/j.jhin.2015.08.027

Pan Y, Zhang D, Yang P, Poon LLM, Wang Q (2020) Viral load of SARS-CoV-2 in clinical samples. Lancet Infect Dis 20:411-412. https://doi.org/10.1016/S1473-3099(20)30113-4

Pani SK, Lin NH, Babu SR (2020) Association of COVID-19 pandemic with meteorological parameters over Singapore. Sci Total Environ. https://doi.org/10.1016/j.scitotenv.2020.140112

Prather KA, Wang CC, Schooley RT (2020) Reducing transmission of SARS-CoV-2. Science 368:1422-1424. https://doi.org/10.1126/ science.abc6197

Prussin AJ, Schwake DO, Lin K, Gallagher DL, Buttling L, Marr LC (2018) Survival of the enveloped virus Phi6 in droplets as a function of relative humidity, absolute humidity, and temperature. Appl Environ Microbiol. https://doi.org/10.1128/AEM.00551-18

Pyankov OV, Sergey B, Pyankova OG, Agranovski IE (2018) Survival of aerosolized coronavirus in the ambient air. J Aerosol Sci 115:158-163. https://doi.org/10.1016/j.jaerosci.2017.09.009

Riddell S, Goldie S, Hill A, Eagle D, Drew T (2020) The effect of temperature on persistence of SARS-CoV-2 on common surfaces. Virol J 17(1):145. https://doi.org/10.1186/s12985-020-01418-7

Sajadi MM, Habibzadeh P, Vintzileos A, Shokouhi S, Miralles-Wilhelm F, Amoroso A (2020) Temperature, humidity and latitude analysis to predict potential spread and seasonality for COVID-19. Soc Sci. https://doi.org/10.2139/ssrn.3550308

Sanders JM, Monogue ML, Jodlowski T, Cutrell JB (2020) Pharmacologic treatments for coronavirus disease 2019 (COVID-19): a review. J Am Med Assoc 323:1824-1836. https://doi.org/10.1001/ jama.2020.6019

Sattar SA, Ijaz MK, Johnson-Lussenburg CM, Springthorpe VS (1984) Effect of relative humidity on the airborne survival of rotavirus SA11. Appl Environ Microbiol 47(4):879-881. https://doi.org/10. 1128/AEM.47.4.879-881.1984

Sekizuka T, Itokawa K, Kageyama T, Saito S, Takayama I, Asanuma H, Naganori N, Tanaka R, Hashino M, Takahashi T, Kamiya H, Yamagishi T, Kakimoto K, Suzuki M, Hasegawa H, Wakita T, Kuroda M (2020) Haplotype networks of SARS-CoV-2 infections in the Diamond Princess cruise ship outbreak. Proc Natl Acad Sci USA 117:20198-20201. https://doi.org/10.1101/2020.03.23. 20041970

Shaman J, Goldstein E, Lipsitch M (2011) Absolute Humidity and Pandemic Versus Epidemic Influenza. Am J Epidemiol 173(2):127135. https://doi.org/10.1093/aje/kwq347

Smither S, Lever M, Findlay J, Eastaugh L (2020) Experimental aerosol survival of SARS-CoV-2 in artificial saliva and tissue culture media at medium and high humidity. Emerg Microbes Infect. https://doi.org/10.1080/22221751.2020.1777906

Stadnytskyi V, Bax C, Bax A, Anfinrud P (2020) The airborne lifetime of small speech droplets and their potential importance in SARSCoV-2 transmission. Proc Natl Acad Sci. https://doi.org/10.1073/ pnas. 2006874117

Suhaimi NF, Jalaludin J, Latif MT (2020) Demystifying a possible relationship between COVID-19, air quality and meteorological factors: evidence from Kuala Lumpur, Malaysia. Aerosol Air Qual Res. https://doi.org/10.4209/aaqr.2020.05.0218

Tellier R, Li Y, Cowling B, Tang J (2019) Recognition of aerosol transmission of infectious agents: a commentary. BMC Infect Dis. https://doi.org/10.1186/s12879-019-3707-y
To K, Tsang O, Leung W, Tam A, Wu T, Lung D, Yip C, Cai J, Chan J, Chik T, Lau D, Choi C, Chen L, Chan WM, Chan KH, Ip J, Ng A, Poon R, Luo CT, Yuen KY (2020) Temporal profiles of viral load in posterior oropharyngeal saliva samples and serum antibody responses during infection by SARS-CoV-2: an observational cohort study. Lancet Infect Dis 20:565-574. https://doi. org/10.1016/S1473-3099(20)30196-1

van Doremalen N, Bushmaker T, Munster VJ (2013) Stability of Middle East respiratory syndrome coronavirus (MERS-CoV) under different environmental conditions. Euro Surveill. https://doi.org/ 10.2807/1560-7917.ES2013.18.38.20590

van Doremalen N, Bushmaker T, Morris D, Holbrook M, Gamble A, Williamson B, Tamin A, Harcourt J, Thornburg N, Gerber S, Lloyd-Smith J, Wit E, Munster V (2020) Aerosol and surface stability of SARS-CoV-2 as compared with SARS-CoV-1. New England J Med. https://doi.org/10.1056/NEJMc2004973

Wang J, Tang K, Feng K, Lin X, Lv W, Chen K, Wang F (2021) Impact of temperature and relative humidity on the transmission of COVID-19: a modelling study in China and the United States. BMJ Open. https://doi.org/10.1136/bmjopen-2020-043863

Wei J, Guo S, Long E, Zhang L, Shu B, Guo L (2021) Why does the spread of COVID-19 vary greatly in different countries? revealing the efficacy of face masks in epidemic prevention. Epidemiol Infect 149:1-17. https://doi.org/10.1017/S0950268821000108

Wilson M (2020) ASHRAE: Keeping air-conditioners on can help control the spread of COVID-19. https://chainstoreage.com/ ashrae-keeping-air-conditioners-can-help-control-spread-covid19. Accessed 20 Aug 2020

World Health Organization (WHO) (2020). Report of the WHO-China Joint Mission on Coronavirus Disease 2019 (COVID19). World Health Organization, Geneva. https://www.who.int/docs/defaultsource/coronaviruse/who-chinajoint-mission-on-covid 19-finalreport.pdf. Accessed 26 Feb 2021

Yang W, Elankumaran S, Marr L (2012) Relationship between humidity and influenza a viability in droplets and implications for influenza's seasonality. PLoS ONE. https://doi.org/10.1371/journal. pone. 0046789

Yao M, Zhang L, Ma J, Zhou L (2020) On airborne transmission and control of SARS-Cov-2. Sci Total Environ. https://doi.org/10. 1016/j.scitotenv.2020.139178

Zhang RY, Li Y, Zhang A, Wang Y, Molina M (2020) Identifying airborne transmission as the dominant route for the spread of COVID-19. Proc Natl Acad Sci USA. https://doi.org/10.4324/ 9781003141402-3

Zhao L, Pan YG, Liu P (2020) Compilation interpretation of guidelines for emergency operation and management of office buildings for dealing with "Novel Coronavirus." Constr Sci Technol 6:15-18 ((in Chinese))

Zhao Y, Aarnink A, Dijkman R, Fabri T, De Jong M, Groot Koerkamp PWG (2011) Effects of temperature, relative humidity, absolute humidity, and evaporation potential on survival of airborne gumboro vaccine virus. Appl Environ Microbiol 78(4):1048-1054. https://doi.org/10.1128/AEM.06477-11

Zou L, Feng R, Huang M, Liang L, Huang H, Hong Z, Yu J, Min K, Song Y, Xia J, Guo Q, Song T, He J, Yen H, Malik P, Wu J (2020) SARS-CoV-2 viral load in upper respiratory specimens of infected patients. N Engl J Med 382:1177-1179. https://doi.org/10.1056/ NEJMc2001737 